\title{
Analyzing the carbon dynamics in north western Portugal: calibration and application of Forest-BGC
}

\author{
M. A. Rodrigues ${ }^{1,2}$, D. M. Lopes ${ }^{3}$, S. M. Leite ${ }^{1,4}$, and V. M. Tabuada ${ }^{1,5}$ \\ ${ }^{1}$ Physics Department, University of Trás-os-Montes e Alto Douro, Vila Real, Portugal \\ ${ }^{2}$ ESSJE - Escola Secundária de S. João do Estoril, Cascais, Portugal \\ ${ }^{3}$ Forest Sciences Department, University of Trás-os-Montes e Alto Douro, Vila Real, Portugal \\ ${ }^{4} \mathrm{CITAB}$ - Centre for the Research and Technology of Agro-Environmental and Biological \\ Sciences, Vila Real, Portugal \\ ${ }^{5}$ IM, I.P. - Meteorological Institute of Vila Real, Portugal
}

Received: 12 March 2010 - Accepted: 23 March 2010 - Published: 13 April 2010

Correspondence to: M. A. Rodrigues (monica.a.rodrigues@ hotmail.com)

Published by Copernicus Publications on behalf of the European Geosciences Union.

\section{Calibration and application of \\ Forest-BGC}

M. A. Rodrigues et al.

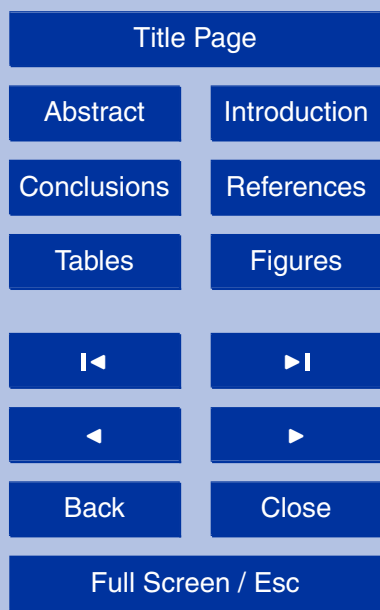

Printer-friendly Version

Interactive Discussion 


\section{Abstract}

Net primary production (NPP) is an important variable that allows monitoring forestry ecosystems fixation of atmospheric Carbon. The importance of monitoring the sequestred carbon is related to the binding commitments established by the Kyoto Pro5 tocol. There are ecophysiologic models, as Forest-BGC that allow for estimating NPP. In a first stage, this study aims to analyze the climate evolution at the Vila Real administrative district during the last decades. The historical information will be observed in order to detect the past tendencies of evolution. Past will help us to predict future. In a next stage these tendencies will be used to infer the impact of these change scenarios

on the net primary production of the forest ecosystems from this study area. For a parameterization and validation of the FOREST-BGC, this study was carried on based on $500 \mathrm{~m}^{2}$ sampling plots from the National Forest Inventory 2006 and are located in several County Halls of the district of Vila Real (Montalegre, Chaves, Valpaços, Boticas, Vila Pouca de Aguiar, Murça, Mondim de Basto, Alijó, Sabrosa and Vila Real). In order to quantify Biomass dinamics, we have selected 45 sampling plots: 19 from Pinus pinaster stands, 17 from Quercus pyrenaica and 10 from mixed of Quercus pyrenaica with Pinus pinaster. Adaptation strategies for climate change impacts can be proposed based on these research results.

\section{Introduction}

20 Global concern about increasing atmospheric concentrations of greenhouse gases, particularly carbon dioxide $\left(\mathrm{CO}_{2}\right)$ and the possible consequences of future climate change have generated interest in understanding and quantifying the role of terrestrial ecosystems in the global carbon cycle. Looking at previous periods, Lucas et al. (2000) have reported that the combustion of fossil fuels has led to a steady increase in the release of carbon dioxide and aerosol particles into the atmosphere since the beginning of the industrial revolution. They conclude that $\mathrm{CO}_{2}$ levels in the atmosphere
ESDD

1, 41-62, 2010

Calibration and application of

Forest-BGC

M. A. Rodrigues et al.

\section{Title Page}

Abstract

Introduction

Conclusions

Tables

References

Figures

14

$\Delta$

4

Back

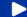

Close

\section{Full Screen / Esc}

Printer-friendly Version

Interactive Discussion

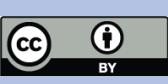


have risen by more than $20 \%$ during this period and should double pre-industrial levels over the next century. According to Puhe and Ulrich (2000), since the late nineteenth century a general warming of global surface temperatures has been observed, especially over continents at latitudes between $40^{\circ} \mathrm{N}$ and $70^{\circ} \mathrm{N}$. They regard the speed 5 of warming as remarkable, having reached an intensity of approximately $0.26{ }^{\circ} \mathrm{C}$ per decade since 1980s. In terms of precipitation, changes indicate a small global positive increase $(1 \%)$ during the twentieth century. The picture in Europe is diverse: annual precipitation changes differ between northern Europe, slight increases, and southern Mediterranean Europe, general decreases in rainfall. In the case of Portugal, analysis 10 carried out by the National Meteorological Service (NMS) for the period 1868-1998 indicates an increase in temperature averaging $0.0074^{\circ} \mathrm{C} /$ year. The trend with respect to rainfall is less clear, although is indicative of an overall decrease, with the most distinct reduction occurring when the data for the month of March are examined over the period ( $-0.29 \mathrm{~mm} / \mathrm{month})$. The evolution of ecosystems is chiefly driven by the adaptation of species and by climate change (Puhe and Ulrich, 2000). At present and for the foreseeable future, climate change represents one of the most significant challenges facing scientists in developing their understanding of how ecosystems adapt to change. Whilst Phat et al. (2004) maintain that global climate change is becoming increasingly apparent, Nemani et al. (2003) have assumed that its impacts are already real (and dramatic). They claim that between 1980 and 2000 the Earth experienced two of the warmest decades in the instrumental record, underwent three intense and persistent El Niño events (1982 to 1983, 1987 to 1988, and 1997 to 1998), and saw noteworthy changes in tropical cloudiness and monsoon dynamics. Several predictions for the future have been reported, such as by Pastor and Post (1988) who suggest a $2-4{ }^{\circ} \mathrm{C}$ mean rise in global temperature with $\mathrm{CO}_{2}$ doubling with greater warming in higher latitudes than near the equator on the basis of general circulation models. The new challenges reported by Phat et al. (2004) focus on the need to gain a deeper understanding of forest ecosystem processes, in particular photosynthesis and transpiration. Running (1994) argues that "global change" is now used as a summary term referring not only

ESDD

$1,41-62,2010$

Calibration and application of Forest-BGC

M. A. Rodrigues et al.

Title Page

Abstract Introduction

Conclusions

Tables References Figures

14

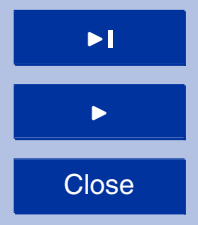

Back

Close

Full Screen / Esc

Printer-friendly Version

Interactive Discussion

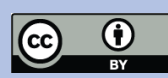


to physical and biological change, but also to socio-economic adjustment across the planet, which will influence the biosphere in ways that only can be projected. Although models are inevitably simplified, imperfect and limited versions of reality (Lucas and Curran, 1999; and Lucas et al., 2000), simulation modelling constitutes an essential 5 tool for evaluating ecosystem activity at space and time scales beyond the limits of direct measurements (Running, 1994). Their benefits are particularly noted for understanding ecosystem function and thus predicting responses to global change (Ryan et al., 1996). Understanding the planet's processes and global ecological system is essential for managing the Earth's resources wisely and for ensuring that sufficient of 10 these are available well into the future. It is important that we investigate how, why, and when these global changes could occur in order to avoid, or at least anticipate and plan for possible emergency situations in the future, thus address the perceived lack of knowledge reported by Lucas et al. (2000), Puhe and Ulrich (2000), and Nemani et al. (2003). The imbalance in the global budget for atmospheric $\mathrm{CO}_{2}$ is one of the most 15 important problems in the study of global change (Cao and Woodward, 1998). Forests are assumed to play an important role in climatic change at the global scale, because they potentially act as a major sink for $\mathrm{CO}_{2}$. It has been suggested that trees should be planted expressly to sequester $\mathrm{CO}_{2}$ and so mitigate the projected further increase in atmospheric $\mathrm{CO}_{2}$ concentrations (Ford and Teskey, 1991). The 21st century has brought new challenges for forest management (Phat et al., 2004) and, in addition to ameliorative actions by people, forest ecosystems could constitute an extremely important tool to deal with climate change. Running et al. (1999) suggest that probably the single most fundamental measure of "global change" of practical interest to humankind is with respect to terrestrial biological productivity - the annual Net Primary 25 Production (NPP), which expresses on a periodic basis carbon net fluxes between atmosphere and terrestrial vegetation through photosynthesis (Goetz and Prince, 1996). Field et al. (1995) report that although conceptually simple, estimation of NPP can be very difficult to measure accurately in situ. This becomes even more problematic when attempting to estimate NPP for large areas Investigators are now focusing attention on

ESDD

1, 41-62, 2010

Calibration and application of Forest-BGC

M. A. Rodrigues et al.

Title Page

Abstract Introduction Conclusions References

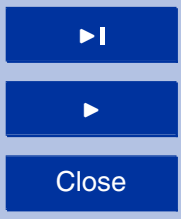

Back

Close

Full Screen / Esc

Printer-friendly Version

Interactive Discussion

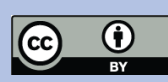


developing more practical methodologies for this task. NPP is complicated not only by difficulties of measurement and estimation, but also because it represents a holistic ecological perspective on ecosystems. Nevertheless, NPP is one of the key variables chosen to analyse the impact of climate change, or equally any other human or natural 5 intervention in ecosystems. Furthermore, relatively few studies have compared NPP estimation from ecophysiological models with measured values from fieldwork.

\section{The model FOREST-BGC}

The model FOREST-BGC was developed at the University of Montana (Running and Coughlan, 1988) where it had been originally applied to coniferous forest stands. It 10 works simulating water, carbon and nitrogen fluxes within homogeneous forests.

FOREST-BGC is a process level ecosystem model developed by Running and $\mathrm{Ne}-$ mani (1988), which calculates canopy interception and evaporation, transpiration, photosynthesis, growth and maintenance respiration, carbon allocation above and belowground, litter fall, decomposition and nitrogen mineralization. This model seeks to 15 establish a compromise between mechanistic detail and simplifying generality that will allow for its implementation in regional scale ecological research. Some assumptions were made in order to simplify the model. Firstly, the model treats fluxes only in the vertical dimension, so that horizontal homogeneity is assumed for any defined area. Secondly, the model treats the forest canopy as a homogeneous three-dimensional 20 leaf of depth proportional to the total leaf area index not projected. Ryan et al. (1996) consider FOREST-BGC as the big leaf model due to these assumptions. The model combines daily and yearly resolution. Running and Coughlan (1988) explain the reasons for this approach. According to them, hydrologic balances, plant water availability and canopy gas exchange processes are most conveniently treated on a daily basics because meteorological data are routinely summarised as daily averages or totals, and these processes react diurnally to environment conditions. However, daily calculation of carbon allocation, litter fall and decomposition processes are not reliable because

ESDD

$1,41-62,2010$

Calibration and application of

Forest-BGC

M. A. Rodrigues et al.

Title Page

Abstract

Introduction

Conclusions

Tables

References

Figures

14

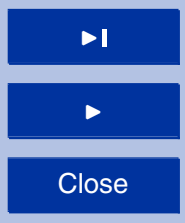

Back

Close

Full Screen / Esc

Printer-friendly Version

Interactive Discussion 
the minimum routinely measurable increment of these processes typically occurs on a monthly basics. LAl is a key variable for controlling NPP and the most important variable in the FOREST-BGC algorithm. However, LAI was not regarded as an input variable in this system. The model estimates LAI indirectly, according to the Eq. (1).

5 leaf area index $=\frac{\text { specific leaf area } \cdot \text { leaf carbon }}{\text { ground surface area }}$

\section{Study area and data}

The Trás-os-Montes area is divided into three slightly different climatic zones: The Hot Zone, the Transition Zone and the Cold Zone. From a thermic point of view the delimitation seems to be between an annual average of $12.0^{\circ} \mathrm{C}$ and $13.0^{\circ} \mathrm{C}$ for the 10 Cold Zone and $14.0^{\circ} \mathrm{C}$ and $15^{\circ} \mathrm{C}$ for the Hot Zone, the Transition Zone showing annual average temperatures ranging from $13.0^{\circ} \mathrm{C}$ to $14.0^{\circ} \mathrm{C}$. The diversity of the repartition of temperatures in a relatively small area is due to a complicated orography and to the fact that it is located in the transition zone between the influence of the Atlantic Ocean and the Continental climate characteristic of the Iberian Peninsula.

15 The selected portions for our study, are all located in the Trás-os-Montes area, each one covers an area of $500 \mathrm{~m}^{2}$. Those portions are part of the national Woodland Inventory of 2006, located in different circumscriptions of the Vila Real district and they are as follows: Montalegre, Chaves, Valpaços, Boticas, Vila Pouca de Aguiar, Murça, Mondim de Basto, Alijó, Sabrosa e Vila Real. For the biomass analysis we use 45 sam-

pling portions (19 of Pinus pinaster, 17 of Quercus pyrenaica, and 10 mixed with Pinus pinaster and Quercus pyrenaica). The populations include trees of different ages, and level of occupation, so as to consider a wide range of tree's dimensions.
ESDD

1, 41-62, 2010

Calibration and application of

Forest-BGC

M. A. Rodrigues et al.

\section{Title Page}

Abstract Introduction

Conclusions References

Tables Figures
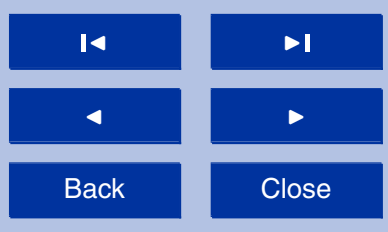

Full Screen / Esc

Printer-friendly Version

Interactive Discussion

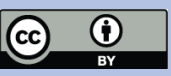




\subsection{Meteorological data}

The state of the atmosphere can be described thanks to a package of measures of the most important climatic elements for its characterization. According to Peixoto and Oort (1992), the most important climatic elements characterizing a climate in a 5 particular area are the precipitations and the temperature.

Leite (1991), states that the repartition of the precipitation in space and time, its changeability and the frequency of its intensity is essential to understand how precipitation works in a particular area. As we have said previously, for our present study we have selected three weather stations: Bragança, Vila Real and Mirandela as they characterize the climate of three sub-areas: Cold Zone, Transition Zone and Hot Zone.

\subsubsection{Data quality}

A cautious and scrupulous study of data, was particularly telling. With a first observation, we noticed that there were figures missing, and that can be caused by machines that have broken down, the impossibility to carry on with the observation whether for 15 lack of an observer or difficult climatic conditions or others. During the preliminary preparation for the series of climatic observations we needed to solve that problem, as the trial methods for statistic analysis require a series of figures equally divided. The available precipitation data in the National system of information on hydrological resources (http://snirh.pt/) regarding the weather station under study, have a high percentage of missing figures and as the missing figures happen to be at the start or at the end of the series, or that they represent a fairly long period regarding the missing figures of the observation in the first or the last years of the record, it seemed to us that it was appropriate to shorten the original series. As mentioned before, thanks to the analysis of our series under study, we realized that, in a lot of days when there had been no records, the observations in nearby weather stations showed the apparent non existence of figures for temperatures and precipitations. The omission of annual totals and some monthly precipitation results, totalizing 25 per cent of the available weather

\section{Calibration and application of Forest-BGC}

M. A. Rodrigues et al.

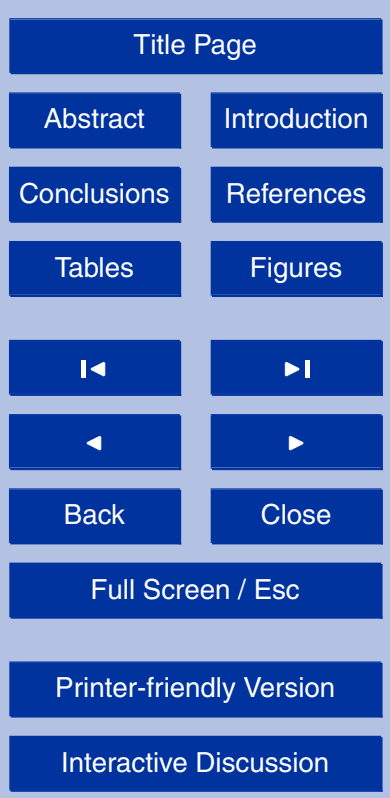

Interactive Discussion

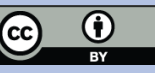


stations represent a series of lack of records for our study, particularly in mountainous zones where the precipitations change a lot from a station to another. This is a recurrent problem in any study on the climate of an area.

As the series of precipitations of the selected stations for our study show a huge 5 number of missing figures, our investigation in methods for filling in the blanks, was restricted to simple procedures, so not to add more discrepancies in the series. In fact, our main goal, as well as filling in the blanks, was not to alter significantly the accurately recorded climatic information in the weather stations. We used the correlation ratio determination method between the weather stations where we noticed the blanks and 10 station as reference. The station we used as a reference was the weather station of Bragança, as it has a minimum lack of records and it is certified by the European Climate Assessment.

\subsubsection{Data analysis}

According to Rodrigues (2009) in Bragança, the annual average temperature has a ten15 dency to increase by $0.16^{\circ} \mathrm{C} / 10$ years, which is due to an increase of $0.3^{\circ} \mathrm{C} / 10$ years in the maximum temperature and to an increase by $0.1^{\circ} \mathrm{C}$ of the minimum temperature. We notice a tendency to increase by $44.9 \mathrm{~mm} /$ decade in the annual precipitations accumulated in Bragança, probably caused by oscillations of great amplitude. In Mirandela, keeping in mind that the series is 50 years shorter, the average temperature 20 decreases by $0.3^{\circ} \mathrm{C} / 10$ years, and that contributes greatly to the decrease of the minimum temperature by $0.4^{\circ} \mathrm{C} / 10$ years. The maximum temperature increases by less than $0.1{ }^{\circ} \mathrm{C} / 10$ years, which is by far, insufficient to counterbalance, in terms of annual averages, the tendency to increase of the maximum temperature. An important characteristic of the climate in Mirandela is that thick radiating fogs are quite frequent in caused by the brutal daily thermic variations that can happen sometimes for nine consecutive days. Mirandela shows fairly inferior accumulated annual precipitation figures, but with an interesting particularity that is a more balanced repartition of the precip-

ESDD

1, 41-62, 2010

\section{Calibration and application of Forest-BGC}

M. A. Rodrigues et al.

\section{Title Page}

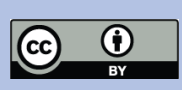


itations throughout the year. In Vila Real, The tendency to decrease of the annual average temperature is quite insignificant, four centesimal of degrees in 10 years, that is caused by a decrease by almost $0.2^{\circ} \mathrm{C} / 10$ years in the maximum temperature. The tendency to increase of the minimum temperature is inferior to a decimal of degrees 5 as such it is not enough to contradict the tendency to decrease of the maximum temperature. As far as the series of precipitation is concerned the record of accumulated annual precipitations presents a slight tendency to decrease by $24.6 \mathrm{~mm} /$ decade.

\subsection{Ground data: measurements of LAI}

The in index of the foliar area (LAI) was obtained thanks to field data and was already 10 known for the Pinus pinaster thanks to Lopes (2005). As regards the Quercus pyrenaica this figure was determined, through the random gathering of 30 leaves in different parts of all the trees of the same species, in a sampling portion chosen at random. Afterwards, each leaf was numbered one by one (from 1 to 30) and each leaf was traced in an acetate sheet. We used the ArcMap software, to determine an area projected by the leaves. After that, the leaves were dehydrated in greenhouses and its anhydride weight was determined afterwards. It was so possible to determine the specific area index (SLA) that links which biomass is the one referring to the area of each leaf. Thanks to the estimated figures of the foliar area for phase 1 and 2, we determined that SLA for the Quercus pyreneica whose value is $33.14 \mathrm{~m}^{2} / \mathrm{kg}$. According to Lopes 20 (2005) the value is of $5.25 \mathrm{~m}^{2} / \mathrm{kg}$ for the specie Pinus pinaster. After we knew the SLA for each species in analysis we underwent the determination of the foliar biomass for each sampling portion.
ESDD

$1,41-62,2010$

Calibration and application of

Forest-BGC

M. A. Rodrigues et al.

\section{Title Page}

Abstract

Introduction

Conclusions

References

Tables

Figures

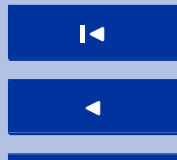

$\rightarrow 1$

Back

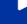

Close

Full Screen / Esc

Printer-friendly Version

Interactive Discussion

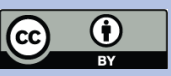




\section{Data processing}

\subsection{Calibration of FOREST-BGC}

ESDD

$1,41-62,2010$

FOREST-BGC was designed to be particularly sensitive to leaf area index (LAI), which is used as the main independent variable for calculating the major physiological pro-

5 cesses in the model. Two input files needed to execute the simulations: one containing the climate input data and another the site parameters and constants. The first file, "filename.CLM", contains daily information from the year in question (optional if simulation includes more than one year), the Julian day (JD), the maximum temperature $\left(T_{\max }\right.$, in $\left.{ }^{\circ} \mathrm{C}\right)$, the minimum temperature $\left(T_{\min }\right.$, in $\left.{ }^{\circ} \mathrm{C}\right)$, the dew point (Dewp, in $\left.{ }^{\circ} \mathrm{C}\right)$, 10 and the total daily amount of rainfall (Prec., in $\mathrm{cm}$ ). The second file, "filename.DAT", contains the input-output processor controls. There are three possible output files: a filename.Day file, providing daily figures for soil water, outflow, evaporation, transpiration, water potential, photosynthesis, and maintenance respiration; a second output file, filename.GRW, which provides annual figures for transpiration, photosynthesis, maintenance respiration, and leaf, stem and root carbon. The Forest-BGC was run, using the averages figures for all the input parameters for each study area with only leaf carbon content changing. The complexity of the model, the number of changing variables and the variability of the study areas had suggested some simplification of the methodology for prediction how Quercus and Pinus ecosystems react.

\section{Results}

In the initial situation, considering the general average of the three portions, the most productive populations were located in the transition zone and the least productive in the Cold Zone. In the area of the transition land and the cold land, PPL is higher in the pure $\mathrm{Pb}$, except for those of the Hot Land where, because of the climatic characteristics, the Pinus specie has adapted so well. In every situation the mixed ones are the least

\section{Calibration and application of Forest-BGC}

M. A. Rodrigues et al.

\section{Title Page}

Abstract Introduction

Conclusions

Tables References Figures

14

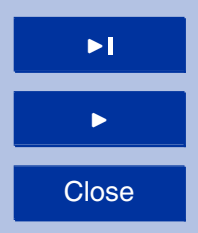

Back

Close

Full Screen / Esc

Printer-friendly Version

Interactive Discussion

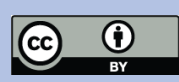


productive, more over the sole simplistic vision of the analysis of production, without considering other aspects like biodiversity need to be carefully pondered. A variation in the maximum temperature affects indistinctively the three types of population, in the three climatic zones in analysis. In the transition zone the mixed populations are the 5 most affected. In the Cold Zone the pure from Quercus are the most affected. In the Hot Zone it is those which are pure of Pinus, followed by those pure of Quercus.

When we change the minimum temperature, the behaviour is identical to the one in the maximum temperature. It is not strange that the Forest-BGC determines the average temperature with the arithmetic average of the maximum and minimum tem10 peratures. In the analysis of the transition zone, the effects of the variation of the precipitations are identical to what happened with the temperatures, but with a minor impact. In the Cold Zone, the variation of precipitations had a greater impact than the change of temperatures. That impact is also greater in the Hot Zone. As a conclusion we can say that the most extreme climatic situation, the variations in precipitations influence more the productivity than the temperature.

From the analysis of the variation of temperatures with precipitations, we noticed that it is the temperature that is more subject to productivity, in the case of the Transition Zone. The tendencies to evolution come from an increase of productivity in this climatic zone. In the Cold zone there is a different characteristic, precipitations are those that terns. In the Hot Zone they don't have a linear behaviour with differentiated behaviours according to the type of population. As a conclusion we can say that is a complex situation with a more erratic behaviour.

\section{ESDD}

$1,41-62,2010$

Calibration and application of Forest-BGC

M. A. Rodrigues et al.

\section{Title Page}

Abstract Introduction

Conclusions References

Tables Figures

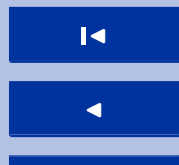

Back

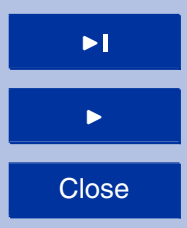

Full Screen / Esc

Printer-friendly Version

Interactive Discussion

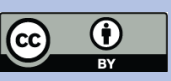




\section{Conclusions}

The principal focus of this study has been on the important role of the NPP in relation climate change, biodiversity and forest management. This work has also examined the applicability and accuracy of the FOREST-BGC as a production simulation 5 model. Results showed that the FOREST-BGC is able to capture the overall pattern of NPP for both ecosystems. In addition to describing the general pattern of NPP in the ecosystems, this ecophysiological model provided some logical explanation about the ecosystems behavior in terms of production. FOREST-BGC was used to simulated the impact of different climate change scenarios on these forest ecosystems' NPP. The ma10 jor limitation of this ecophysiological model was its inability to incorporate atmospheric $\mathrm{CO}_{2}$ as input. Results could change significantly if this factor was taken into account. Regardless this increase or decrease of NPP the most significant fact is that climate change will have a very strong impact on the production of ecosystems and in carbon sequestration, and consequently in the balance of those ecosystems. This investiga-

tion can be said to have contributed towards an advancement in the understanding of the essential role played by forest ecosystems, mainly due to their constituting extremely important reservoirs of carbon in the globe.

Acknowledgements. To the Investigation Project PTDC/AGR-CFL/68186/2006.

\section{References}

Cao, M. and Woodward, F. I.: Net primary and ecosystem production and carbon stocks of terrestrial ecosystems and their responses to climate change, Global Change Biol., 4, 185198, 1998.

Field, C. B., Randerson, J. T., and Malmstrom, C. M.: Global Net Primary Production: combining ecology and remote sensing, Remote Sens. Environ., 51, 74-88, 1995.

25 Ford, E. D. and Teskey, R. O.: The concept of closure in calculating carbon balance of forest: accounting for differences in spatial and temporal scales of component processes, Tree Physiol., 9, 307-324, , 1991.
ESDD

$1,41-62,2010$

Calibration and application of

Forest-BGC

M. A. Rodrigues et al.

\section{Title Page}

Abstract

Introduction

Conclusions

Tables

References

Figures

14

$\Delta$

4

Back

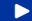

Close

\section{Full Screen / Esc}

Printer-friendly Version

Interactive Discussion

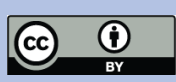


Goetz, S. J and Prince, S. D.: Remote sensing of net primary production in boreal forest stands, Agr. Forest Meteorol., 78, 149-179, 1996.

Leite, S. M.: Contribution to the study of the climate of Duero Basin: spectral analysis and discriminant analysis of climatological fields, PhD Thesis, University of Trás-os-Montes and Alto Douro, Vila Real, Portugal, 319 pp., 1991.

Lopes, D.: Estimating net primary production in Eucalyptus globulus and Pinus pinaster ecosystems in Portugal, PhD Thesis, Kingston University, London, 259 pp., 2005.

Lucas, N. S. and Curran, P. J.: Forest ecosystem simulation modelling: the role of remote sensing, Prog. Phys. Geog., 23, 2, 391-423, 1999.

10 Lucas, N. S., Curran, P. J., Plummer, S. E., and Danson, F. M.: Estimating the stem carbon production of a coniferous forest using an ecosystem simulation model driven by the remotely sensed red edge, Int. J. Remote Sens., 21, 4, 619-613, 2000.

Nemani, R. R., Keeling, C. D., Hashimoto, H., Jolly, W. M., Piper, S. C., Tucker, C. J., Myneni, R. B., and Running, S. W.: Climate-driven increases in global terrestrial net primary production 15 from 1982 to 1999, Science, 300, 1560-1563, 2003.

Pastor, J. and Post, W. M.: Response of northern forest to $\mathrm{CO}_{2}$ induced climate change, Nature, 334, 6177, 55-58, 1988.

Peixoto, J. P. and Oort, A. H.: Physics of Climate, American Institute of Physics, New York, 1992.

20 Phat, N. K., Knorr, W., and Kim, S.: Appropriate measures for conservation of terrestrial carbon stocks - Analysis of trends of forest management in Southeast Asia, Forest Ecol. Manag., 191, 283-299, 2004.

Puhe, J. and Ulrich, B.: Global Climate Change and human impacts on forest ecosystems, Ecological Studies, 143, Springer, 592 pp., 2000.

Rodrigues, M. A.: Contribution for the study of the impact of the alterations of climate in the rate of fixation of carbon in the forest ecosystems of the district of Vila Real, Master Thesis, University of Trás-os-Montes and Alto Douro, Vila Real, Portugal, 98 pp., 2009.

Running, S. W. and Coughlan, J. C.: A General Model of Forest Ecosystem Processes for Regional Applications. I. Hydrologic Balance, canopy gas exchange and primary production processes, Ecol. Model., 42, 125-154, 1988.

Running, S. W. and Nemani, R. R.: Relating seasonal patterns of the AVHRR vegetation index to simulated photosynthesis and transpiration of forests in different climates, Remote Sens. Environ., 24, 347-367, 1988.

\section{Calibration and application of Forest-BGC}

M. A. Rodrigues et al.

\section{Title Page}

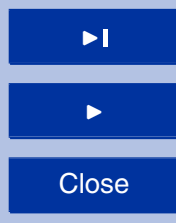


Running, S. W.: Testing FOREST-BGC ecosystem process simulation across a climate gradient in Oregon, Ecol. Appl., 4, 2, 238-247, 1994.

Running, S. W., Nemani, R. N., Glassy, J. M., and Thornton, P. E.: MODIS daily photosynthesis (PSN) and annual net primary production (NPP) product (MDO17): Algorithm theoretical basis document, NTSG, University of Montana, 59 pp., 1999.

Ryan, M. G., Hunt Jr., E. R., McMurtrie, R. E., Agren, G. I., Aber, J. D., Friend, A. D., Rastetter, E. B., Pulliam, W. M., Raison, R. J., and Linder, S.: Comparing models of ecosystem function for temperate conifer forest. I. Model description and validation, in: Global Change: Effects on Forests and Grasslands, edited by: Breymeyer, A., Hall, D. O., Melillo, J. M., and Ågren,

\section{ESDD}

$1,41-62,2010$

Calibration and application of

Forest-BGC

M. A. Rodrigues et al.

\section{Title Page}

\section{Abstract}

Introduction

Conclusions

References

Tables

Figures

14

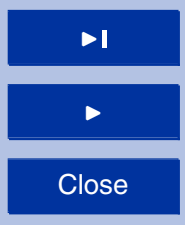

Back

Close

Full Screen / Esc

Printer-friendly Version

Interactive Discussion

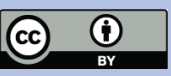




\section{ESDD}

$1,41-62,2010$

\section{Calibration and application of \\ Forest-BGC}

Table 1. NPP estimation $\left(\mathrm{kg} \mathrm{ha}^{-1}\right.$ year $\left.^{-1}\right)$ by the simulation of Forest-BGC for diferent climate scenarios with variation of temperature $(\Delta T)$ and variation of rainfall $(\Delta R)$.

\begin{tabular}{|c|c|c|c|c|c|c|c|c|c|}
\hline Region & Sampling Portions & Initial & $\Delta T_{\max }$ & $\Delta T_{\min }$ & $\Delta T_{\max +\min }$ & $\Delta R$ & $\Delta R+\Delta T_{\max }$ & $\Delta R+\Delta T_{\min }$ & $\Delta R+\Delta T_{\max +\min }$ \\
\hline \multirow[t]{3}{*}{ Transition } & Pinus pinaster & 2590 & 2607 & 2586 & 2598 & 2595 & 2601 & 2593 & 2597 \\
\hline & Quercus pyrenaica & 2095 & 2107 & 2088 & 2097 & 2096 & 2102 & 2091 & 2097 \\
\hline & Mixed & 1599 & 1655 & 1656 & 1655 & 1639 & 1638 & 1638 & 1639 \\
\hline \multirow[t]{3}{*}{ Cold } & Pinus pinaster & 2584 & 2523 & 2560 & 2495 & 2452 & 2398 & 2430 & 2372 \\
\hline & Quercus pyreneica & 2079 & 1418 & 1464 & 1493 & 3433 & 3367 & 3411 & 3344 \\
\hline & Mixed & 1607 & 1596 & 1583 & 1524 & 1655 & 2204 & 2233 & 2182 \\
\hline \multirow[t]{3}{*}{ Hold } & Pinus pinaster & 2118 & 2600 & 2784 & 2753 & 1846 & 1844 & 1858 & 1855 \\
\hline & Quercus pyreneica & 2631 & 2103 & 2206 & 2191 & 2030 & 2016 & 2121 & 2105 \\
\hline & Mixed & 1596 & 1582 & 1685 & 1669 & 1511 & 1496 & 1601 & 1586 \\
\hline
\end{tabular}

M. A. Rodrigues et al.

\section{Title Page}

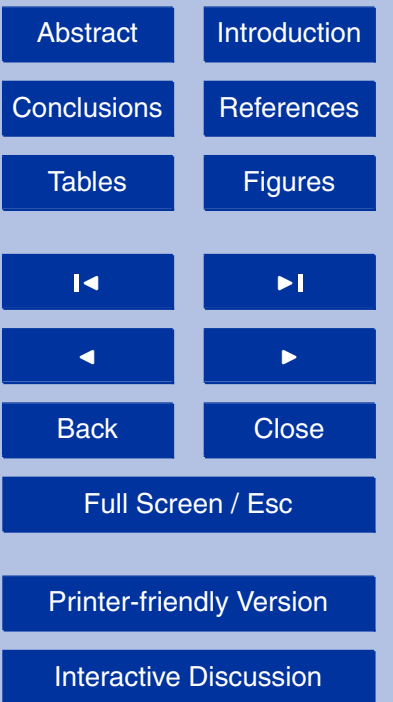




\section{ESDD}

$1,41-62,2010$

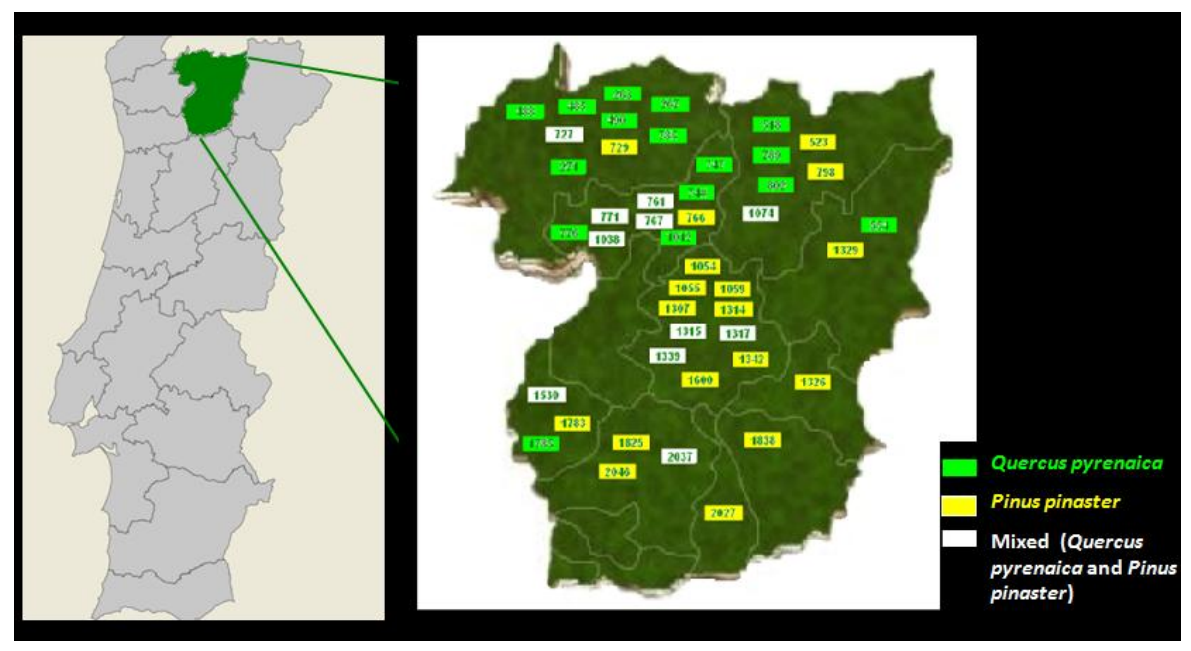

Calibration and application of Forest-BGC

M. A. Rodrigues et al.

\begin{tabular}{|c|c|}
\hline \multicolumn{2}{|c|}{ Title Page } \\
\hline Abstract & Introduction \\
\hline Conclusions & References \\
\hline Tables & Figures \\
\hline I4 & \\
\hline 4 & $-\mathbf{I}$ \\
\hline Back & Close \\
\hline Full Screen / Esc
\end{tabular}

Fig. 1. Location of the study area and inclusion of the sampling portions (Rodrigues, 2009).

Printer-friendly Version

Interactive Discussion 


\section{ESDD}

$1,41-62,2010$

Calibration and application of

Forest-BGC

$$
\text { Vila Real } L T=-24,6 \mathrm{~mm} / 10 \text { years }
$$

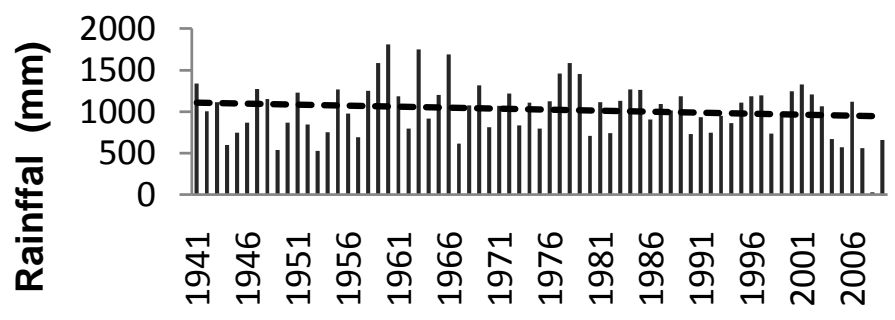

\section{years}

Fig. 2. Representation of the annual rainfall Vila Real station series.
M. A. Rodrigues et al.

Title Page

Abstract

Introduction

Conclusions

References

Tables

Figures

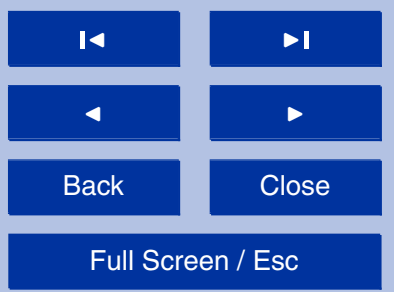

Printer-friendly Version

Interactive Discussion 


\section{ESDD}

$1,41-62,2010$

Calibration and application of

Forest-BGC

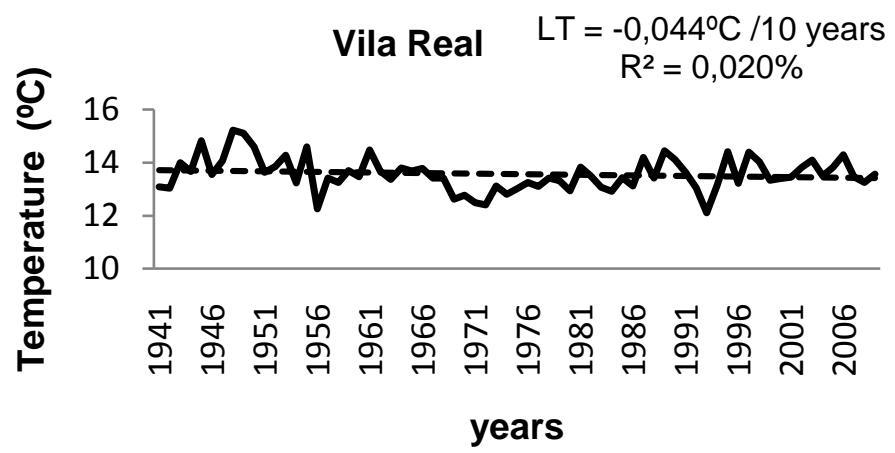

Fig. 3. Representation of the annual mean temperature Vila Real station series.
M. A. Rodrigues et al.

Title Page

Abstract

Introduction

Conclusions

References

Tables

Figures

14

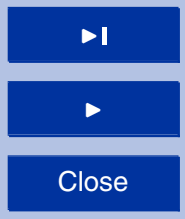

Back

Full Screen / Esc

Printer-friendly Version

Interactive Discussion

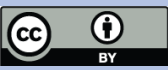




\section{ESDD}

$1,41-62,2010$

Calibration and application of

Forest-BGC

\section{Bragança $\quad \mathrm{LT}=44,9 \mathrm{~mm} / 10$ years}

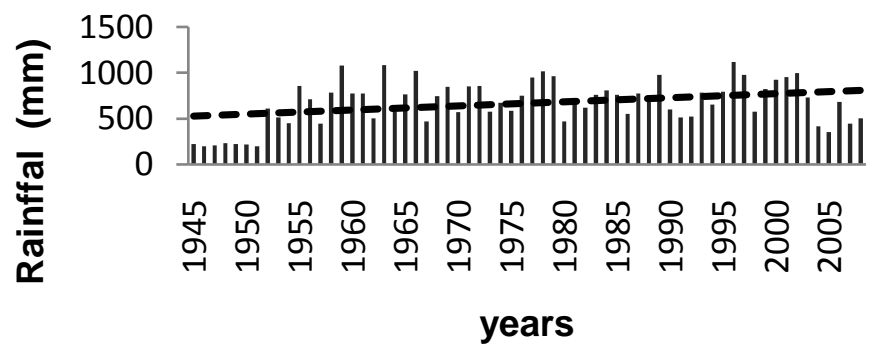

Fig. 4. Representation of the annual rainfall Bragança station series.

M. A. Rodrigues et al.

Title Page

Abstract

Introduction

Conclusions

References

Tables

Figures

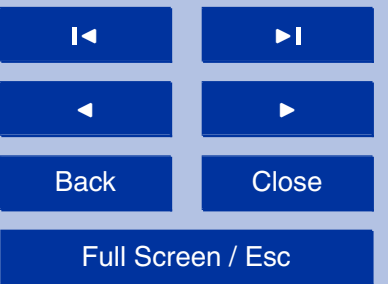

Printer-friendly Version

Interactive Discussion 


\section{ESDD}

$1,41-62,2010$

Calibration and application of

Forest-BGC

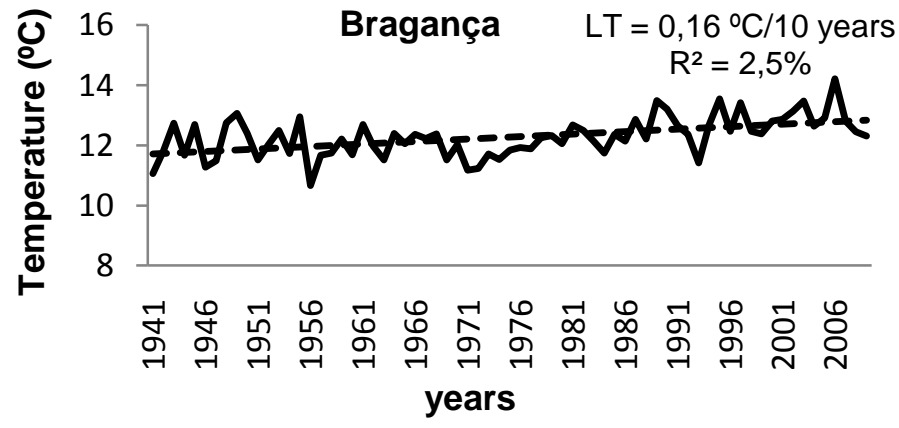

Fig. 5. Representation of the annual mean temperature Bragança station series.
M. A. Rodrigues et al.

Title Page

Abstract

Introduction

Conclusions

References

Tables

Figures

14

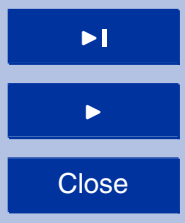

Back

Full Screen / Esc

Printer-friendly Version

Interactive Discussion 


\section{ESDD}

1, 41-62, 2010

Calibration and application of

Forest-BGC

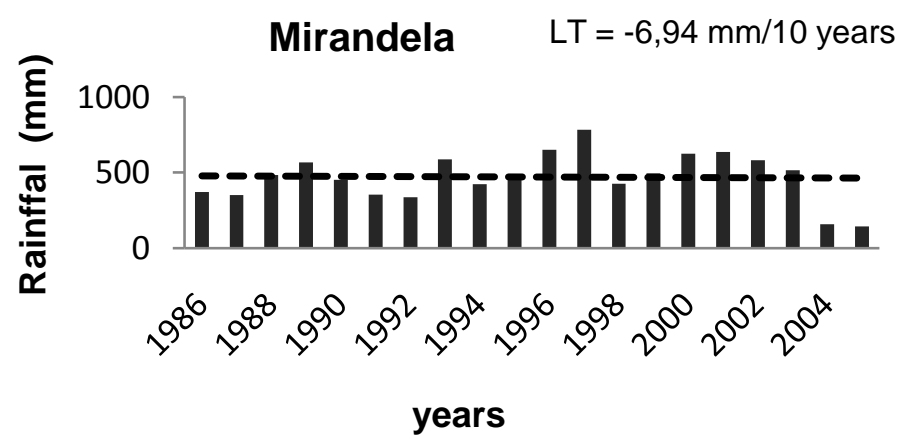

M. A. Rodrigues et al.

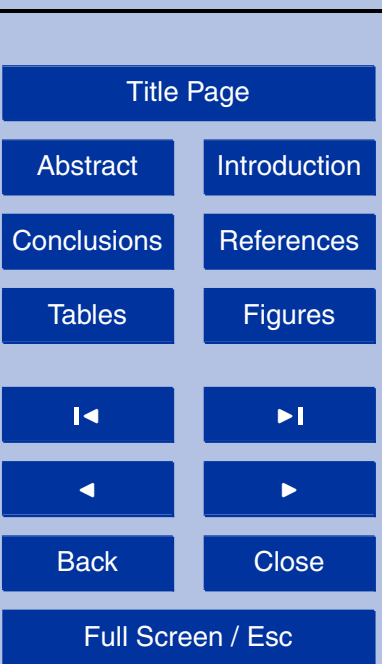

Printer-friendly Version

Interactive Discussion 


\section{ESDD}

1, 41-62, 2010

Calibration and application of

Forest-BGC

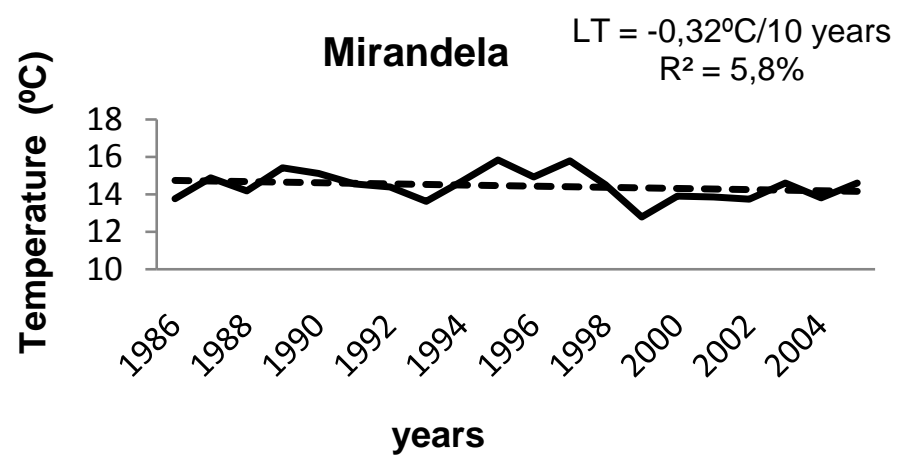

M. A. Rodrigues et al.

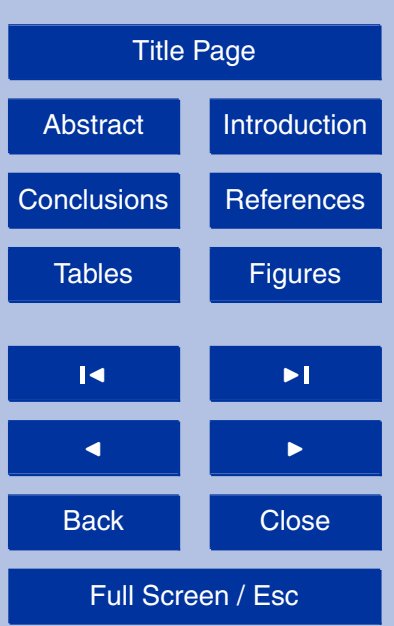

Fig. 7. Representation of the annual mean temperature Mirandela station series.

Printer-friendly Version

Interactive Discussion 